\title{
The Views of Pre-Service Teachers Regarding the Effectiveness of Peer Assisted Learning Method in the Science and Technology Laboratory Practices Course
}

\author{
Yeter Şimşekli ${ }^{1}$, Dilek Zeren Özer ${ }^{1}$, Sema Nur Güngör ${ }^{1}$ \\ ${ }^{1}$ Department of Math and Science Education, Uludag University, Bursa, Turkey \\ Correspondence: Dilek Zeren Özer, Uludag University, Faculty of Education, Department of Math and Science \\ Education, Bursa, Turkey.
}

Received: October 31, 2017

Accepted: November 20, 2017

Online Published: November 28, 2017

doi:10.11114/jets.v5i12.2750

URL: https://doi.org/10.11114/jets.v5i12.2750

\begin{abstract}
The purpose of this study is to show the views of pre-service teachers about peer-assisted learning method which is a common practice. The peer student group of the research sample ( $\mathrm{N}: 40)$ consisted of 2 nd grade pre-service primary teachers attending the Uludag University Faculty of Education during the 2010-2011 academic year and taking the Science and Technology Laboratory Practices course. The peer teacher group (N:10), on the other hand, consisted of 3rd grade pre-service science teachers attending the same faculty and taking the Community Service Practices course. The peer teachers assisted the peer students in the Science and Technology Laboratory Practices course for 10 weeks. This a phenomenological research, which is a qualitative research method. The Peer Teacher Evaluation Form and the Peer Student Evaluation Form, which included 6 open-ended questions, were used for the/our data collection. The data were analyzed through content analysis. It was concluded that peer-assisted learning method makes the Science and Technology Laboratory Practices course more effective, benefits peer teachers and peer students, and contributes to group work.
\end{abstract}

Keywords: peer-assisted learning, peer student, peer teacher, science and technology laboratory practices

\section{Introduction}

Peer-assisted learning is a process which can be implemented at different educational levels where students support each other. In this process, teachers, peer groups and friends with whom individuals are in continuous interaction fulfill the duty of teaching (Demirel \& Yagci, 2011). This is called peer-assisted learning method and can be defined as a method where a student conveys knowledge to his/her peer(s) inside or outside the classroom under the control of his/her teacher (Arun, Altay, \& Celenk, 2010; Guven \& Aydin, 2007). Topping (1996) defines peer education as the process in which individuals who are in a similar social group and are not a professional teacher help each other to learn and teach. Peer-assisted learning makes use of social learning that stems from peer group's positive characteristics and the identification and social interaction of peers with one another (Unver \& Akbayrak, 2013). Constructivist thought this is based on the theories of Vygosky (Slavin, 2013). One of the prominent principles in Vygosky's thoughts is cognitive apprenticeship. Cognitive apprenticeship refers to the process in which a learner gains expertise step by step through interaction with an expert, an adult, an older person, or a more advanced peer. In addition, Vygotsky argues that cognitive development is closely related to the inputs provided by others and highlights cognitive support, which is one of the basic concepts of social learning view (the assistance provided by a more skillful peer or adult) (Slavin, 2013). The inputs provided by others (e.g. knowledge and skill) should be necessary, and there should be differences between peers for cognitive development to take place. In such a case, one of the two peers can treat the other as an educator. As stated by Unver \& Akbayrak (2013), it is a peer cooperation, but not peer education where peers have equal level of cognitive knowledge.

It is reported that peer-assisted learning method ensures active participation of students in lessons, allows peer teachers and peer learners to practice more through one-to-one study, reduces the possibility of repeating mistakes by correcting the mistakes instantly through instant feedback during teaching, enables learners to strengthen and further their knowledge, improves learning level in the school, facilitates collaboration among students, and increases social interaction (Guven \& Aydin, 2007; Tuncer \& Kahveci, 2009). 
The literature indicates that peer-assisted learning method is effectively used in both general education and special education arrangements. In special education, this method is used for having children with normal development support their peers with special needs who are at the same age as them or at a similar developmental level to them (Christopher, Hansen, \& MacMillan 1991; Fujiki, Brinton, Hart, \& Fitzgerald, 1999; Gelzheiser, Mclane, Meyers, \& Pruzek, 1998; Guven \& Aydin, 2007; Ozaydin, Iftar, \& Kaner, 2008; Warr-Leeper, 2001; Wolery \& Wilbers, 1994; Visoky \& Poe, 2000, Yildirim, 2002). In general education, peer-assisted learning method is used in health and medical education more and more (Yu, Wilson, Sing, Lemanu, Hawken, \& Hill, 2011; Johnson, 2002; Secomb, 2008; Hendelman \& Boss, 1986; Cate \& Durning, 2007; Nnodim, 1997, Krych, March, Bryan, Peake, Pawlina, \& Carmichael, 2005; Tuncer \& Kahveci, 2009). Peer-assisted learning research is less frequent in the field of science education. For example, Ozdemir \& Erol (2011) developed a teaching model with a hybrid approach which includes; peer teaching, group and classroom discussions, group problem-solving, homework demonstration, problem-solving, and problem-posing to teach the uncertainty principle and explored the effects of this model on academic achievement and permanence. Ramaswamy, Harris, \& Tschirner (2001) employed peer-assisted learning method in science and engineering education and proposed a new model that would be used in such education.

Laboratory method is a way that allows students to learn subjects in a laboratory or a specially-equipped classroom through observation, experimentation, learning by doing-experience, and demonstration by an individuals or a group (Ergun \& Ozdas, 1997). However, there are some obstacles to achieving the cognitive, social, and psycho-motor development intended with this method used for teaching scientific knowledge by establishing a connection between theoretical knowledge and practice (Kocakulah \& Savas, 2013). Among these obstacles are the existence of science subjects students have difficulty in learning; students' incomplete content knowledge; students' imperfect knowledge of laboratory instruments, supplies, and equipment; the incapability of students to use them effectively; lack of opportunity for students to carry out experiments; students' lack of interest in the subjects; lack of materials; overcrowded classrooms; inadequate classrooms; inadequate course hours; lack of teacher guidance; and timidity to ask teachers for help (Aydogdu, 1999; Celik, Pektas, \& Demirbas, 2012; Stasinakis \& Kalogiannakis, 2017; Gunes, Sener, Germi, \& Can, 2013; Kaya, Cepni, \& Kucuk, 2004; Ulucinar, Cansaran, \& Karaca, 2004). Based on the above-mentioned problems, the main purpose of this study is to determine the opinions of pre-service teachers about incorporating the peer-assisted learning method to the Science and Technology Laboratory Practices course. In the present study, it was guaranteed that two student groups of different ages and from different branches (peer teachers and peer students) would engage in mutual interaction through peer-assisted learning during the experiments conducted in the Science and Technology Laboratory Practices course. The views and comments of the peer teachers and the peer students were collected at the end of this interaction.

It is considered that the use of peer-assisted learning in laboratory practices will contribute to students' learning of scientific concepts and principles; improve their experimenting skills by allowing them get familiar with laboratory instruments, supplies, and equipment; and facilitate the elimination of problems resulting from lack of teacher guidance and timidity of students to ask teachers for help.

\section{Method}

This is a phenomenological research, which is a qualitative research method. Phenomenological research is a type of research that deeply explores the phenomena which we encounter in our life but we do not know or think on in detail (Yildirim \& Simsek, 2011) Phenomenological research also elaborates on the feelings, perceptions, and thoughts of the participants about their experiences as well as how they construct them and create consciousness for themselves (Patton, 2002; Aydin, 2014). After the researcher collects data about the addressed subject at the analysis stage, he tries to determine "the experiences and meanings about the research subject constructed by the individuals in the research sample" by using such data (Aydin, 2014).

\subsection{Study Group}

The study group consists of 40 2nd grade pre-service science teachers attending Uludag University Faculty of Education Department of Elementary Education and taking the Science and Technology Laboratory Practices course (peer students) and 10 3rd grade pre-service teachers attending the Department of Science Teaching of the same faculty and taking the Community Service Practices course (peer teachers). The study lasted 10 weeks and was conducted during the spring semester of the 2010-2011 academic year. The peer students were divided into 10 groups and each group had 4 students. One peer teacher was appointed to each group. The pre-service science teachers had learned in the 2nd grade the experiments which would be conducted in the laboratory. They were also re-informed about these experiments by the instructor of the course before the beginning of each experiment/class. It was assumed that the pre-service science teachers had adequate knowledge of the relevant subjects, and that the groups were equal to each other as the present study did not aim to make any comparison of scientific success. 


\subsection{Data Collection Tools}

Data were collected through two evaluation forms: The Peer Teacher Evaluation Form and the Peer Student Evaluation Form. The initial versions of the data collection tools consisted of 7 open-ended questions. The draft questions included in the data collection tools were examined by domain experts to ensure the validity of their content. Based on the received comments/opinions, the Peer Teacher Evaluation Form and the Peer Student Evaluation Form were rearranged in terms of content and form. Based on these comments/opinions, 1 question was removed from each form. Each evaluation form was finalized to contain 6 open-ended questions. The questions in the forms are presented in Appendix A and Appendix B.

\subsection{Data Analysis}

All of the peer teachers (T1-10) and 36 of the peer students (S1-36) answered the questions in the evaluation forms. The data were analyzed through content analysis, and their frequency (f) values were calculated. According to Cohen, Manion, \& Morrison (2007), content analysis refers to summarizing and reporting the main content of the written information in hand and the messages such information contains. Content analysis involves four stages: processing the qualitative research data obtained from documents, coding the data, finding themes, and organizing and interpreting results (Yildirim \& Simsek, 2011). In the present study, coding was done and themes were obtained based on the pre-determined screening and selection criteria in the first stage. Then the data were organized and grouped based on the themes. They were digitally presented and finally interpreted based on the findings.

\subsection{Validity and Reliability}

To ensure the internal validity of the study, support was received from a person specialized in qualitative research and research design, data collection, data analysis, and data interpretation. Raw data and all documents were examined by this expert. The interpretation of the data was revised based on the expert's comments/suggestions and opinions.

The raw data were expressed without any comments. The external validity of the study was sustained by including direct quotations from the literature.

In addition, a diverse research sample was formed by incorporating students attending the primary teacher education and the science teacher education. For this study, these students were enrolled in the Science and Technology Laboratory Practices course and the Community Service Practices course.

The reliability (interval reliability) of the study was examined, too. Based on the general perspective of the research, attention was given on whether the process in which the data were obtained, themes were created, and such themes were interpreted were consistent with one another. To ensure the external reliability of the study, the raw data were compared with results continuously.

\subsection{Implementation Steps}

1) 10 voluntary pre-service teachers enrolled in the Community Service Practices course were assigned as peer teachers.

2) 40 peer students attending the department of primary teacher education were divided into 10 groups of 4 . The peer students were appointed to the groups randomly.

3) A peer teacher was randomly appointed to each peer student group.

4) The experiments to be carried out were determined; necessary instructions were given to the peer teachers; and explanations were given about the process and what they need to do during the process.

5) The peer teachers guided the peer students during the implementation of the experiments.

6) At the end, measurement tools were administered to the peer teachers and the peer students.

7) During the experiments, a researcher/expert observed the peer teachers and the peer students. When a peer teacher did not come to class, the members of his/her group were distributed to the groups of other peer teachers.

\section{Results}

Whether the peer teachers and the peer students were satisfied with this practice (i.e. learning process through peer-assisted learning) which was conducted in the Community Service Practices course their opinions were asked. 10 $(100 \%)$ of the peer teachers and $32(88.9 \%)$ of the peer students stated that they were satisfied with the practice. However, $4(11.1 \%)$ of the peer students stated that they were not satisfied with the practice.

The answers of the peer teachers and the peer students to the question asking the aspects of the practice with which they were satisfied fell into 3 main themes: "situations concerning the peer teachers"; "situations concerning the peer students"; and "situations concerning the teaching process". The peer-teachers and the peer-students expressed different views under these main themes. 
Table 1. The Views of the Peer Teachers Concerning the Positive Aspects of the Practice

\begin{tabular}{|c|c|}
\hline The peer teachers' views & f \\
\hline \multicolumn{2}{|l|}{ a. Situations Concerning the Peer Teachers } \\
\hline a.1. I had a chance to improve myself in my own field. & 2 \\
\hline a.2. I felt closer to the profession of teaching. & 2 \\
\hline a.3. I noticed an improvement in my communication skills. & 2 \\
\hline a.4. I had a chance to share what I knew. & 2 \\
\hline a.5. I had a chance to carry out a lot of experiments which we did not do in science classes. & 1 \\
\hline a.6. I noticed that it was beneficial in te & 1 \\
\hline a.7. Thanks to this process, I learned and improved my way of expressing myself to people & 1 \\
\hline a.8. I had a chance to meet students having different learning styles. & 1 \\
\hline \multicolumn{2}{|l|}{ b. Situations Concerning the Peer Students } \\
\hline b.1. I noticed that the practice increased peer students' su & 3 \\
\hline learned by the peer students immediately. & 2 \\
\hline b.3. I noticed that getting the answers of the questions about the conducted experiments instantly prevented mislearning. & 1 \\
\hline b.4. I & 1 \\
\hline $\begin{array}{l}\text { b.5. I concluded that it was a beneficial learning process because it allowed noticing and correcting the misconceptions of } \\
\text { the peer students instantly. } \\
\text { c. Situations Concerning the Teaching Process }\end{array}$ & 1 \\
\hline c.1. I observed th & 3 \\
\hline Total Views & 23 \\
\hline \multicolumn{2}{|l|}{$\begin{array}{l}\text { According to Table 1, in regard to the aspects of the practice with which they were satisfied, the peer teachers stated that } \\
\text { they had a chance to improve themselves in their own field; they felt closer to the profession of teaching; they noticed } \\
\text { an improvement in their communication skills; they had a chance to share what they knew; they had a chance to carry } \\
\text { out different experiments; they noticed that it was beneficial in terms of group work; thanks to this process, they learned } \\
\text { to better express themselves to people; and they had a chance to meet students having different learning styles. Thinking } \\
\text { that he had a chance to develop himself in his own field, T6 stated, "I contributed to the things about my field." } \\
\text { Thinking that peer teachers became closer to the profession of teaching, T5 stated, "...there was a big difference } \\
\text { between the first time in that class and the last time in that class. It was first time that I had felt like a real teacher." } \\
\text { Thinking that his communication skills got better, T9 stated, "...I think it contributed to the advancement of our social } \\
\text { communication skills." Thinking that thanks to the process, he had a chance to share his knowledge, T6 stated, "I had a } \\
\text { chance to share knowledge." In terms of the situations concerning the peer students, the peer teachers stated that they } \\
\text { noticed that the practice increased the peer students' success and the interest in the course, and non-understood/difficult } \\
\text { concepts and methods were learned by the peer students immediately. As to the situations concerning the teaching } \\
\text { process, the peer teachers stated that the teaching and laboratory process was efficient. }\end{array}$} \\
\hline
\end{tabular}

Table 2. The Views of the Peer Students Concerning the Positive Aspects of the Practice

\begin{tabular}{l}
\hline The Peer Students' Views \\
\hline a. Situations Concerning the Peer Techers \\
a.1. The fact that our peer teachers were also students made us ask questions to them more comfortably. \\
a.2. I thought the peer teachers developed themselves and gained experience in their own field. \\
a.3. I concluded that the practice contributed to the peer teachers in the matter of teacher-student communication. \\
b. Situations Concerning the Peer Students \\
b.1. I was satisfied with that when we halted during the experiments, our peer teacher guided us and answered our \\
questions. \\
b.2. I was satisfied with that our peer teacher enabled us to get to the results of the experiments more easily by giving clues \\
about how to carry them out. \\
b.3. I thought I was bad at science. However, I noticed that the practice enabled me to acquire information \\
b.4. I concluded that it provided permanent learning. \\
b.5. I noticed that it had a positive impact on my social development. \\
c. Situations Concerning the Teaching Process \\
c.1. I think the lessons were enjoyable. \\
c.2. I observed that it was beneficial in terms of lessons efficiency. \\
c.3. I think it contributed to group work. \\
\hline Total Views
\end{tabular}

The Table 2 shows the answers of the peer students to the question, "Which aspects of the practice were you satisfied with?". They fell under 3 themes: "situations concerning the peer teachers"; "situations concerning the peer students"; and "situations concerning the teaching process". In regard to the situations concerning the peer teachers, the peer 
students stated that they were able to ask questions to the peer teachers more comfortably because they knew that they were also students. S12 expressed his view in this matter as follows: "As he was a peer teacher, we asked our questions more comfortably." The peer students also stated that the peer teachers gained experience and improved their student-teacher communication skills. S5 expressed his view about the experience gained by the peer teachers as follows: "Since it was practical, they saw the situations which they can face during experiments and gained experience in this matter..."

As to the situations concerning the peer students, they stated that they were satisfied with the fact that when they halted during the experiments, the peer teacher guided them and answered their questions; they were satisfied with the fact that the peer teacher allowed them to reach the results of the experiments more easily by giving them clues about how to carry them out; the practice enabled them to acquire more knowledge on science subjects; and it provided permanent learning. S22 expressed his satisfaction with his peer teacher as follows: "He usually made us conduct the experiments. He warned us when he had to. I was satisfied with my peer teacher."

In terms of the situations concerning the teaching process, the peer students stated that the lessons were enjoyable; the practice was beneficial; and it contributed to a group work.

Table 3. The Views of the Peer Teachers Concerning the Negative Aspects of the Practice

The Peer Teachers' Views
a Situations Concerning the Peer Teachers
a.1. I noticed that as it was a different practice, it caused us to suffer from inexperience in the beginning.
a.2. I sometimes had difficulty in controlling the group.
b. Situations Concerning the Peer Students
b.1. I think little interest of the peer students in science reduced its benefits.
b.2. In my opinion, the fact that the peer students did not bring necessary materials to the class had a negative impact.
b.3. I observed that the efficiency of the lesson decreased when the peer students came to the class without 3
studying/preparing for the lesson.
b.4. I noticed the fact that we helped the peer students in every experiment which
caused reluctance.
b.5. In my opinion, the fact that the peer students did not have adequate theoretical knowledge about some of the 2
experiments had a negative impact on the practice.
c. Situations Concerning the Teaching Process
c.1. I observed that it was difficult to implement the process in a crowded classroom environment.
Total Views

Table 3 shows the answers of the peer teachers to the question, "Which aspects of the practice were you dissatisfied with?" The answers fell under 3 themes: "situations concerning the peer teachers"; "situations concerning the peer students"; and "situations concerning the teaching situation." In regard to the aspects they were dissatisfied with, the peer teachers stated that little interest of the peer students in science reduced its benefits; the fact that the peer students did not bring necessary materials to the class had a negative impact; the efficiency of the lesson decreased when the peer students came to the class without studying/preparing for the lesson; the fact that they helped the peer students in every experiment caused reluctance among them; the fact that the peer students did not have adequate theoretical knowledge about some of the experiments had a negative impact on practice; it was difficult to implement the process in a crowded classroom environment; as it was a different practice, it caused them to suffer from inexperience in the beginning; and they sometimes had difficulty controlling the group. T7 expressed his view as follows: “...in my opinion, their unfamiliarity with and lack of interest in science reduced the potential benefits of this process". The view of T3 about the reluctance of the peer students was as follows: "Our taking part in every experiment led to some indolence. This is because; they expected us to do activities in every experiment." 
Table 4. The Views of the Peer Students Concerning the Negative Aspects of the Practice

The Peer Teachers' Views

a. Situations Concerning the Peer Teachers

a.1. In my opinion, the fact that our peer teacher sometimes did not have adequate knowledge about the 6 experiments caused us to doubt his competence in teaching.

a.2. I thought the process may have disrupted the other lessons of the peer teachers.

\title{
b. Situations Concerning the Peer Students
}

b.1. I think the peer teacher was not beneficial for me.

b.2. I think if our teacher had been better, I would have been happier.

b.3. I noticed that the fact that our peer teacher sometimes did not come to the class caused us to have problems. 1

\begin{abstract}
Total Views
Table 4 presents the answers of the peer students to the question, "Which aspects of the practice were you dissatisfied with?" Their answers fell under 2 themes: "situations concerning the peer teachers" and "situations concerning the peer students". In regard to the situations concerning the peer teachers, the peer students stated that the fact that their peer teacher sometimes did not have adequate knowledge about the experiments caused them to doubt their competence in teaching, and that the process might have disrupted the other lessons of the peer teachers. As to the situations concerning themselves, the peer students thought that the peer teacher was not beneficial to them; if their teacher had been better, they would have been happier; and the fact that their peer teacher sometimes did not come to the class caused them to have problems. S27 expressed his doubt about the knowledge of his peer teacher as follows: "Knowing that he was a student made me ask the question, 'Is he wrong?' very often. I sometimes doubted his knowledge."

When the question, "Would it be beneficial if this learning practice was maintained?" was asked both to the peer teachers and the peer students, all of the peer teachers and 32 of the peer students stated that it should be maintained. Those peer students who expressed a negative view in response to this question did so because they were dissatisfied with the peer teacher.
\end{abstract}

Table 5 and Table 6 below present the findings obtained from the peer teachers and the peer students in response to the question, "Do you have any recommendations for this practice to be improved?"

Table 5. The Recommendations of the Peer Teachers for the Improvement of the Practice

\begin{tabular}{l} 
The Peer Teachers' Recommendations \\
\hline a. Situations Concerning the Peer Teachers \\
a.1. I think consultancy should be provided not to all experiment groups in the science laboratory, but only to those groups \\
that request a peer teacher. \\
a.2. I believe that more responsibility should be given to peer teachers. \\
a.3. I think it would be better if peer teachers were inspected by course teachers more. \\
b. Situations Concerning the Peer Students \\
b.1. I believe that the experiment groups made up of peer students should consist of few students. \\
b.2. I think the theoretical knowledge of peer students should be increased. \\
c. Situations Concerning the Teaching Process \\
c.1. I think an appropriate physical environment will make a positive contribution. \\
c.2. I believe that the theoretical part of the course should involve different teaching methods. \\
\hline Total Views \\
Table 5 shows the answers of the peer teachers to the question, "What do you recommend for this practice to be \\
improved?" Their answers fell under 3 themes: "situations concerning the peer teachers", "situations concerning the \\
peer students", and "situations concerning the teaching process". In regard to the situations concerning themselves, the \\
peer teachers stated that consultancy should be provided not to all experiment groups, but only to those groups that \\
request a peer teacher. The view of T7 in this matter was as follows: “...assistance could have been provided only for \\
those who asked for a consultant. I think it could have been more efficient..." They also highlighted that more \\
responsibility should be given to peer teachers, and they should be inspected by course teachers more. As to the \\
situations concerning the peer students, the peer teachers stated that the experiment groups should consist of fewer \\
students. In regard to the situations concerning the teaching process, they stated that an appropriate physical \\
environment should be provided, and different teaching methods and techniques should be used.
\end{tabular}


Table 6. The Recommendations of the Peer Students for the Improvement of the Practice

\begin{tabular}{|c|c|}
\hline The Peer Students' Recommendations & f \\
\hline \multicolumn{2}{|l|}{ a. Situations Concerning the Peer Teachers } \\
\hline a.1. I think peer teachers should be selected based on specific criteria (e.g. high knowledge level). & 5 \\
\hline a.2. It would be better if peer teachers were completely informed of the experiments to be conducted. & 2 \\
\hline a.3. I noticed that peer teachers should be inspected by course teachers more. & 2 \\
\hline $\begin{array}{l}\text { a. } 4 \text {. I think it would be more beneficial if experiments were presented by a different } \\
\text { peer teacher every week. }\end{array}$ & 1 \\
\hline $\begin{array}{l}\text { a.5. I think it would be better if the theoretical parts of experiments were presented } \\
\text { by peer teachers at the beginning of each lesson. }\end{array}$ & 1 \\
\hline a.6. I noticed that it would be positive if peer teachers worked with different groups every week. & 1 \\
\hline a.7. I believe that more responsibility should be given to peer teachers. & 1 \\
\hline \multicolumn{2}{|l|}{ b. Situations Concerning the Peer Students } \\
\hline \multicolumn{2}{|l|}{ c. Situations Concerning the Teaching Process } \\
\hline c.1. I think it would be good if this practice was applied to other courses, too. & 3 \\
\hline c.2. I think this practice should be maintained. & 10 \\
\hline Total Views & 28 \\
\hline \multicolumn{2}{|c|}{$\begin{array}{l}\text { Table } 6 \text { shows the answers of the peer students to the question, "What do you recommend for this practice to be } \\
\text { improved?" Their answers fell under } 3 \text { themes: "situations concerning the peer teachers", "situations concerning the } \\
\text { peer students", and "situations concerning the teaching process". In regard to the situations concerning the peer teachers, } \\
\text { the peer students stated that peer teachers should be selected based on specific criteria (e.g. high knowledge level); peer } \\
\text { teachers should completely be informed of the experiments to be conducted; peer teachers should be inspected by } \\
\text { course teachers more; experiments should be presented by a different peer teacher every week; and more responsibility } \\
\text { should be given to peer teachers. In regard to themselves, the peer students stated that there should be fewer peer } \\
\text { students in the groups. As to the situations concerning the teaching process, the peer students stated that the practice } \\
\text { should be maintained and applied to other courses, too. Sample student views in these matters are as follows: S34: "It } \\
\text { would be beneficial if peer teachers were selected better and selected teachers were tested at the end of every work." } \\
\text { S23: "This practice should be maintained; the number of groups should be reduced; and guidance should be provided by } \\
\text { more peer teachers. The implementation of this practice in different experiments should be maintained. It should be } \\
\text { maintained in both semesters." }\end{array}$} \\
\hline
\end{tabular}

To determine what type of assistance was provided by the peer teachers to the peer students during the implementation, the question, "How Did You Help Your Peer Students During the Practice?" was addressed to the peer teachers while the question, "How Did Your Peer Teacher Help You During the Practice?" was addressed to the peer students. Table 7 and Table 8 show the answers given by the peer teachers and the peer students.

Table 7. The Views of the Peer Teachers about Their Contributions to the Peer Students

\begin{tabular}{l}
\hline The Peer Teachers' Views \\
\hline a. Knowledge \\
a.1. I think I helped more by sharing theoretical knowledge and defining concepts. \\
b. Experiments \\
b.1. I think I helped them correct their misconceptions. \\
b.2. I believe that I informed them about laboratory materials and devices. \\
b.3. I think we did the experiments together when the peer students could not do \\
the experiments or asked for their help. \\
c. Evaluation \\
c.1. I believe that I enabled them to reach relevant results by asking them questions at the end of the experiments. \\
c.2. I think I helped my peer students when they had any deficiency or asked any question. \\
\hline Total Views
\end{tabular}

Table 7 shows the answers of the peer teachers to the question, "How Did You Help Your Peer Students During the Practice?" Their answers fell under 3 themes: "knowledge", "experiments", and "evaluation". Under the theme of knowledge, the peer teachers stated that they helped the peer students more by sharing theoretical knowledge and giving the definitions of concepts. Under the theme of experiments, they stated that they helped them correct their misconceptions; they informed them about laboratory materials and devices; and they did the experiments together when the peer students could not do the experiments or asked for their help. Under the theme of evaluation, they stated that they enabled the peer students to reach relevant results by asking them questions at the end of the experiments, and they helped their peer students when they had any deficiency or asked any question. Sample student views in these matters are as follows: T10: "When my peer students had incomplete theoretical knowledge, I helped them by 
completing their theoretical knowledge. I sometimes helped them by giving them lectures on the experiments with the relevant tasks assigned by my teachers during the experiments as they conducted them. I only helped them establish a testing apparatus when they halted. Apart from that, I tried to guide them by asking questions to them. However, in general, they tried to conduct their experiments by themselves." T8: "We tried to help our students by answering their questions when they had a deficiency or did not understand a point." T7: "I only helped with the definition of certain concepts. It was mostly during the correction of misconceptions."

Table 8. The Views of the Peer Students about the Contributions of the Peer Teachers

\begin{tabular}{l}
\hline The Peer Students' Views \\
\hline a. Knowledge \\
a.1. I think the peer teacher helped by explaining theoretical knowledge and concepts with meanings that we did not 20 \\
know. \\
a.2. I believe that they helped by giving information prior to the experiments. \\
b. Experiments \\
b.1. In my opinion, the fact that we did the experiments together with our peer teacher when we could not do them made a 17 \\
positive contribution. \\
b.2. I think they gave information about the experiments. \\
b.3. I believe that they helped by informing us of the points which we had to take into account during the experiments. \\
c. Evaluation \\
c.1. I observed that they made evaluations about the experiments at the end. \\
c.2. I noticed that they helped us when we had any deficiency or we asked them a question. \\
c.3. I think they strengthened our knowledge of relevant subjects by giving \\
examples from the daily life. \\
c.4. I observed that the peer teacher inquired whether or not the experiment achieved its goal. \\
c.5. I believe that they helped us reach relevant results and interpret the experimental results at the end. \\
Total Views
\end{tabular}

Table 8 shows the answers of the peer students to the question, "How Did Your Peer Teachers Help You During the Practice?" Their answers fell under 3 themes: "knowledge", "experiments", and "evaluation". The peer students stated that the peer teacher explained theoretical knowledge and the concepts whose meanings they did not know and they gave information prior to the experiments. Under the theme of experiments, the peer students stated that they did the experiments together with their peer teacher when they could not do them; the peer teachers gave information about the experiments; and they helped by informing them of the points which they had to take into account during the experiments. Under the theme of evaluation, the peer students stated that they made evaluations about the experiments at the end.; they helped them when they had any deficiency or they asked them a question; they strengthened their knowledge of relevant subjects by giving examples from the daily life; and they helped them reach relevant results and interpret the experimental results at the end. Sample student views in these matters are as follows: S8: "When a student had incomplete knowledge, the peer teacher contributed to the understanding of the problems by asking questions. He made a more permanent learning possible by demonstrating how to carry out the experiments. At the end of the experiment, he provided the students with important feedbacks so that students can clearly understand the points that were unclear to them." S36: "During the implementation of the experiments, our teacher helped us by demonstrating what to do and how to do it. He helped us interpret the results of the experiments being conducted."

\section{Discussion}

This study covered a sample practice for the use of peer-assisted learning method in the Science and Technology Laboratory Practices course. Within the scope of the study, the pre-service science and technology teachers assisted the pre-service primary teachers in the Science and Technology Laboratory Practices course through peer-assisted learning method. All of the peer teachers and majority of the peer students were seen to be satisfied with the practice conducted under the scope of the Community Service Practices course. In their study focusing on student views regarding peer-assisted learning, Goldsmith et al. (2006) detected positive student views concerning the enhancing influence of peer-assisted learning on students' basic skills and practical performance. Riessman (1990) also obtained similar results and reported that peer teaching leads to important experiences and positive impacts on students (both those who receive assistance and those who give assistance) both in cooperative learning environments and in one-to-one learning environments.

The peer teachers expressed the personal aspects in which they were satisfied with the practice as follows: they had a chance to improve themselves in their own fields; they felt closer to the profession of teaching; they improved their communication skills; they had a chance to share what they knew; they had a chance to conduct different experiments; they learned how to better express themselves to people ; the practice was beneficial in terms of group work; and they had a chance to meet students having different learning styles. In the study exploring the experiences of peer teachers, 
Tariq (2005) stated that all participants had a good learning experience. According to Mastropieri et al. (2003), the positive interaction between peer learners and peer educators has a positive influence on the learning experiences of students in both groups. There are some studies highlighting that when peer teaching is applied, peer teachers repeat and learn a subject better while explaining it to a student or shaping it in a way he will explain it. In addition, the views and knowledge of students about learning are improved when they have an opportunity to share their feelings and thoughts about the teaching process (Carpenter, Bloom, \& Boat, 1999; Gartner \& Riessman, 1993). There are studies indicating that peer teaching improves students' communication skills (Tariq, 2005; Loke and Chow, 2007) and teaching and learning skills as well as skills to talk and make a presentation before other people (Howman, 2006). In the present study, the peer students thought that their success and interest in lessons increased; they learned new concepts and methods more easily; and the teaching process turned out to be more efficient. In a study employing the peer teaching method, it was seen that the children receiving peer assistance were better at reading comprehension in comparison to the children not receiving such assistance (Fuchs, Fuchs, \& Kazdan, 1999). Goldsmith et al. (2006) found out that an improvement occurred in the learning capacities of the students involved in such a practice, and that they were satisfied with the practice. In a study comparing the competencies of students on certain covered subjects following peer education, majority of the students stated that they felt more self-confident and knowledgeable after such educational process (Tariq, 2005). Sen (2010) and Krych et al. (2005) also support the data obtained in the present study.

The peer students expressed the personal aspects in which they were satisfied with the practice as follows: when they halted during the experiments, the peer teacher answered their questions; the peer teacher enabled them to reach the results of the experiments more easily by giving clues about how to conduct them; the practice enabled them to acquire more knowledge on science subjects; it provided permanent learning; they could ask questions to the peer students comfortably and gained experience in communication; lessons were enjoyable in terms of the teaching process; and the practice was quite beneficial and contributed to group work. In the study exploring the influence of peer education conducted by Iwasiw and Goldenberg (1993), while the skill of dressing a wound was taught to a group of students through peer support, it was taught to another group of students by the help of educators. They determined that an improvement occurred in the skill scores and the knowledge levels of the students learning the above-mentioned skill under the guidance of peers. The literature contains similar studies reporting that peer teaching enhances the knowledge, skills, and performance of students (Ashwin, 2003; Karabulut, 2003; Goldsmith et al., 2006). Landyshewsky (2000) explored the effectiveness of peer education model in improving physiotherapy students' skill to solve clinical problems and found that peer-assisted learning enhanced student performance in theoretical and practical processes, and the students undergoing peer-assisted learning experienced less anxiety during such processes. Some other studies also report that this method reduces the stress of students (Field et al., 2007; Tariq, 2005). In the study carried out by Unver (2007), all of the participating students stated that they could ask questions more easily when they were with their peers, and that the peer-assisted learning method facilitated their learning. In that study, it was also concluded that lack of a hierarchical relationship between peer teachers and peer students leads to a comfortable learning environment that is open to communication, allows students to ask questions without hesitation, and provides a good communication experience and solidarity between two groups, which has a positive influence on students' learning. In the present study, the answers of the peer teachers and the peer students to the questions about the positive aspects of the practice led to a similar finding.

The peer teachers expressed the aspects in which they were dissatisfied with the practice as follows: little interest of the peer students in science reduced its benefits; the peer students did not bring necessary laboratory materials to the class; the peer students came to the class without studying/preparing for the lesson; the peer students did not have adequate theoretical knowledge of experiments; it was difficult to implement the process in a crowded classroom environment; as it was a different practice, it caused them to suffer from inexperience in the beginning; and they sometimes had difficulty in controlling the group. In Gill et al. (2006), students stated that peer teaching method was a very different experience for them; it improved their teaching and learning skills; and it enhanced their communication skills. In the present study, four of the peer students stated, as a negative aspect, that the students came to the class without studying/preparing for it. However, in the study in which they evaluated the impacts of a training program conducted by peers on students, Hurley et al. (2003) indicated that students fulfilled the expectations of teachers and prepared for lessons well.

The peer students expressed the aspects in which they were dissatisfied with the practice as follows: the peer teachers were not beneficial; they would have been happier if their teacher was better; they were not content with the absenteeism of the peer teachers; and imperfect knowledge of the peer teachers about the experiments led to doubt among the students. Parkin (2006) stressed that teachers to be selected in peer education should be knowledgeable and experienced in this matter. Loke and Chow (2007) report that sometimes peer educators fail to answer the questions of learners, which helps peers achieve learning through cooperation among themselves. From this perspective, peer 
education model is a model that facilitates the cooperative learning of two groups and allows them to develop themselves.

In response to the question about whether the practice should be maintained, all of the peer teachers and majority of the peer students stated that it should be maintained. Few peer students who expressed negative opinions in this matter did so because they were not adequately satisfied with the peer teacher.

The recommendations of the peer teachers for the improvement of this practice are as follows: peer teachers should be assigned only to those groups which request them; more responsibility should be given to them; they should be inspected by course teachers more frequently; an appropriate physical environment should be provided; and experiment groups should consist of fewer peer students. The recommendations of the peer students in this matter are as follows: the number of peer students in groups should be reduced; peer teachers should be selected based on specific criteria; peer teachers should be completely informed of experiments; peer teachers should be inspected more; the experiments should be presented by a separate peer teacher every week; and more responsibility should be given to peer teachers. Weaver and Cotrell (1986) also reached similar results and stated that peer evaluation lays more responsibility on students, encourages them in their studies, provides a more transparent study framework, and increases attention to learning. The peer students' recommendations that peer teachers should be selected based on specific criteria are supported by Santee and Garavalia (2006). They examined 20 studies in which peer education model was implemented and eventually indicated that peer teachers should be selected from among voluntary individuals. Research (Goldsmith et al., 2006; Tariq, 2005; Loke \& Chow, 2007) shows that if peer teachers are selected from among voluntary individuals, peer education model can be implemented in a more efficient and successful way. In the light of this information, it is recommended to be careful while selecting peer teachers and take peer teacher criteria into consideration during selection.

From the perspective of the peer teachers, they helped the peer students during the experiments by sharing their knowledge with them, defining unknown concepts for them, correcting their misconceptions, and providing assistance when the peer students failed or needed aid in using laboratory materials and devices, asked a question, and had a deficiency. From the perspective of the peer students, the peer teachers helped the peer students by explaining theoretical knowledge and the concepts whose meanings they did not know, giving them information about the experiments prior to such experiments, providing assistance about the points to take into account during the experiments, making evaluations about the experiments at the end, answering the questions asked to them, and providing aid for reaching the results and interpreting the experiment results. As noted by Aydogdu (1999), these findings of the present study concerning peer-assisted learning method imply that this learning method can solve such problems of students as lack of teacher guidance and timidity of students to ask teachers for help.

In summary, it was seen that majority of the pre-service teachers deemed peer-assisted laboratory practices beneficial, thought that it made a lot of contribution to them, and stated that it should be maintained. Based on these views, it was concluded that this practice will contribute to pre-service teachers (peer teachers and peer students) both in their learning processes and in their future careers. Seferoglu (2001) also emphasized that the use of peer education improves teachers' professional skills and increases professional solidarity and relationship among teachers.

It is considered that this study will contribute to research aimed at enhancing the quality of peer-assisted education and laboratory practices and to educators who attempt to improve the quality of science and technology laboratory practices.

\subsection{Practical Recommendations}

- University or faculty administrations may make plans for students who are good at particular lessons (peer teachers) to support students with incomplete knowledge about such lessons (peer students).

- Peer teachers may be encouraged not to miss classes for peer-assisted learning to be effective.

- It should be ensured that peer teachers go to the class with full preparation and cover the relevant subjects and do the relevant activities or experiments in advance (before they go to the class).

- In peer-assisted learning process, course teachers should inspect peer teachers during their interactions with peer students and intervene in case of any problem.

\section{References}

Arun, N. C., Altay, F., \& Celenk, B. (2010). Effect of direct assessment and peer asessment approaches on achievement in teaching volleyball game, 11th Biannual International Sports Sciences Congress, Antalya.

Ashwin, P. (2003). Peer support: Relations between the context, process and outcomes for the students who are supported, Instructional Science, 31, 159-173. https://doi.org/10.1023/A:1023227532029

Aydin, S. (2014). Case Study. M. Metin (Ed). Scientific Research Methods in Education. (s.287-311).Ankara, Turkey, 
Pegema Publishing.

Aydogdu, C. (1999). Identification of difficulties in chemistry laboratory applications. Hacettepe University Journal of Education, 15, 30-35.

Carpenter, C. D., Bloom, L. A., \& Boat, M. B. (1999). Guidelines for special educators: Achieving socially valid outcome. Intervention in School and Clinic, 34(3), 143-149. https://doi.org/10.1177/105345129903400304

Cate, O. T., \& Durning, S. (2007). Peer teaching in medical education: twelve reasons to move from theory to practice, Medical Teaching, September; 29(6), 591-599.

Celik, H., Pektas, H. M., \& Demirbas, M. (2012). Investigation of Status of Primary School Teaching Students As Regards Installing and Figuring Out Electrical Circuits. M.U. Ataturk Egitim Fakultesi Egitim Bilimleri Dergisi, 35, 85-103.

Christopher, J. S., Hansen, D. J., \& MacMillan, V. M. (1991). Effectiveness of a peer helper intervention to increase children's social interactions. Behavior Modification, 15(1), 22-50. https://doi.org/10.1177/01454455910151002

Cohen, L, Manion, L., \& Morrison, K. (2007). Research Methods in Education.New York, Routledge.

Demirel, O., \& Yagci, E. (2011). Principles and Methods of Teaching for Anatolian High School Teachers, Ministry of National Education State Books, Ankara.

Ergun, M., \& Ozdaş, A. (1997). Teaching Principles and Methods. İstanbul: Kaya Publishing.

Field, M., Burke, M. J., McAllister, D., \& Lloyd, D. (2007). Peer-assisted learning: a novel approach to clinical skills learning for medical students, Medical Education, 41, 411-418. https://doi.org/10.1111/j.1365-2929.2007.02713.x

Fuchs, L. S., Fuchs, D., \& Kazdan, S. (1999). Effects of peer-assisted learning strategies on high school students with serious reading problems. Remedial and Special Education, 20(5), 309-318. https://doi.org/10.1177/074193259902000507

Fujiki, M., Brinton, B., Hart, C. H., \& Fitzgerald, A. H., (1999). Peer acceptance and friendship language impairment. Topics in Language Disorders, 19(2), 34-48. https://doi.org/10.1097/00011363-199902000-00005

Gartner, A., \& Riessman, F. (1993). Peer-tutoring: Toward a new model. ERIC Digest. ERIC "Clearinghouse on Teaching and Teacher Education. Washington DC. ED362506 (Erisim tarihi 12 Agustos 2005) www.ericfacility.net/databases /ERIC_Digests/ed362506.html

Gelzheiser, L. M., Mclane, M., Meyers, J., \& Pruzek, R. M. (1998). IEP-specified peer interaction needs: accurate but ignored. Exceptional Children, 65(1), 51-65. https://doi.org/10.1177/001440299806500104

Gill, D., Parker, C., \& Spooner, M. (2006). Tomorrw's doctors and nurses: peer assisted learning, The Clinical Teacher, 3(1), 13-18. https://doi.org/10.1111/j.1743-498X.2006.00087.x

Goldsmith, M., Stewart, L., \& Ferguson, L. (2006). Peer learning partnership: an innovative strategy to enhance skill acquisition in nursing students, Nurse Education Today, 26, 123-130. https://doi.org/10.1016/j.nedt.2005.08.001

Gunes, M. H., Sener, N., Topal, G. N., \& Can, N. (2013). Teacher and Student Assessments Regarding to Use of Science and Technology Laboratory. University of Dicle Journal of Ziya Gökalp Education Faculty, 20, 1-11

Guven, Y., \& Aydin, A. (2007). Primary Teachers' Opinions about Peer Tutoring for Children with Special Needs, Anadolu University Journal of Social Sciences, 1, 415-432.

Hendelman, W. J., \& Boss, M. (1986). Reciprocal peer teaching by medical students in the gross anatomy laboratory. Journal of Medical Education, 61(8), 674-680. https://doi.org/10.1097/00001888-198608000-00007

Howman, M. (2006). The PAL Project-Peer Assisted Learning in Medicine, http://www.ucl.ac.uk/acme/the\%20project.doc 07/11/2006

Hurley, F. K., Mckay, W. D., Scott, M. T., \& James, M. B. (2003). The supplemental Instruction project: peer-devised and delivered tutorials, Medical Teacher, 25(4), 404-407. https://doi.org/10.1080/0142159031000136743

Iwasiw, L. C., \& Goldenberg, D. (1993). Peer teaching among nursing students in the clinical area: effects on students learning, JAN, 18(4), 659-668.

Johnson, J. H. (2002). Importance of dissection in learning anatomy: Personal dissection versus peer teaching, Clinical Anatomy, 15(1), 38-44. https://doi.org/10.1002/ca.1090

Karabulut, O. O. (2003). Investigation of Peer Education Effectiveness of University Students on Family Planning, Yuksek Lisans Tezi, Ege University Institute of Health Sciences, Izmir. 
Kaya, A., Cepni, S., \& Kucuk, M. (2004). Fizik ogretmenlerinin laboratuarlara yonelik hizmet ici ihtiyaclari icin bir program gelistirme calismasi, Kastamonu University Kastamonu Education Journal, 12(1), 41-56.

Kocakulah, A., \& Savas, E. (2013). Effect of the Science Process Skills Laboratory Approach Supported with Peer-Instruction on Some of Science Process Skills of Pre-service Teachers. Necatibey Faculty of Education Electronic Journal of Science and Mathematics Education, 7(2), 46-77. https://doi.org/10.12973/nefmed202

Krych, A. J., March, C. N., Bryan, R. E., Peake, B. J., Pawlina, W., \& Carmichael, S. W. (2005). Reciprocal peer teaching: Students teaching students in the gross anatomy laboratory, Clinical Anatomy, 18(4), 296-301. https://doi.org/10.1002/ca.20090

Ladyshewsky, R. (2000). Peer-assisted learning in clinical education: a review of terms and learning principles. Journal of Physical Therapy Education, 14, 15-22.

Loke, Y. A., \& Chow, F. (2007). Learning partnership-the experience of peer tutoring among nursing students: A qualitative study, International Journal of Nursing Studies, 44, 237-244. https://doi.org/10.1016/j.ijnurstu.2005.11.028

Mastropieri, A. M., Scruggs, E. T., Spencer, V., \& Fontana, J. (2003). Promoting success in high school world history: peer tutoring versus guided notes, Learning Disabilities Research \& Practice, 18(1), 52-65. https://doi.org/10.1111/1540-5826.00057

Nnodim J. O. (1997). A controlled trial of peer-teaching in practical gross anatomy, Clinical Anatomy, 10(2), 112-117. https://doi.org/10.1002/(SICI)1098-2353(1997)10:2<112::AID-CA7>3.0.CO;2-X

Ozaydin, L., Tekin-Iftar, E., \& Kaner, S. (2008). Arkadaslik Becerilerini Gelistirme Programinin Ozel Gereksinimi Olan Okul Oncesi Cocuklarinin Sosyal Etkilesimlerine Etkisi. Ankara University Faculty of Educational Sciences Journal of Special Education, 9(1), 15-32.

Ozdemir, E., \& Erol, M. (2011). Uncertainty Principle of Quantum Physics: Effects Of Hybrid Teaching On Academic Achievement And Retention, Dokuz Eylul University Journal of Buca Education Faculty, 29, 20-35.

Parkin, V. (2006). Peer education: the nursing experience, The Journal of Continuing Education in Nursing, 37(6), 257-264. https://doi.org/10.3928/00220124-20061101-04

Patton, M. Q. (2002) .Qualitative Evaluation and Research Methods (3rd ed.).Thousand Oaks, CA: Sage.

Ramaswamy, S. Harris, I., \& Tschirner, U. (2001). Student Peer Teaching: An Innovative Approach to Instruction in Science and Engineering Education. Journal of Science Education and Technology, 10(2), 165-171. https://doi.org/10.1023/A:1009421231056

Riessman, F. (1990). Peer-Tutoring. (Erisim tarihi 28 Agustos 2005). www.ncrel.org/sdrs/areas/issues/students/atrisk/at61k20.htm

Santee, J., \& Garavalia, L. (2006). Peer tutoring programs in health professions schools, American Journal of Pharmaceutical Education, 70(3), 1-10. https://doi.org/10.5688/aj700370

Secomb, J. (2008). A systematic review of peer teaching and learning in clinical education, Journal of Clinical Nursing, 17(6), 703-716. https://doi.org/10.1111/j.1365-2702.2007.01954.x

Seferoglu, S. (2001). Peer coaching: a new approach in professional development of teachers, Education and Science, $26,20-25$.

Sen, A. I. (2010). Effects of Peer Teaching and Microteaching on Teaching Skills of Pre-Service Physics Teachers. Education and Science, 35(155), 78-88.

Slavin, R. E. (2013). Egitim Psikolojisi. Ankara: Nobel Akdemik Yayincilik.

Stasinakis, K. P., \& Kalogiannakis, M. (2017). Analysis of a Moodle-based training program about the Pedagogical Content Knowledge of Evolution Theory and Natural Selection. World Journal of Education, 7(1), 14-32. https://doi.org/10.5430/wje.v7n1p14

Tariq, N. V. (2005). Introduction and evaluation of peer-assisted learning in first-year undergraduate bioscience, BEE-j, 6.

Topping, K. (1988).The Peer Tutoring Handbook, Croom Helm, London.

Tuncer, A. T., \& Kahveci, G. (2009). Az Goren 8. Sinif Ogrencilerine Kavram Haritasiyla Ozet Cikarma Becerisinin Akran Araciligi ile Ogretimi, Journal of Turkish Educational Sciences, 7(4), 853-877.

Ulucinar, S., Cansaran, A., \& Karaca, A. (2004). Fen bilimleri laboratuvar uygulamalarinin degerlendirilmesi. Turk 
Egitim Bilimleri Dergisi, 2(4), 465-475.

Unver, V. (2007). Formation of the model for improving laboratory and clinical skills of the students at the school of nursing, Gulhane Military Medical Academy (GMMA). Institute of Health Sciences, Doctorate Thesis, Ankara.

Unver, V., \& Akbayrak, N. (2013). Peer Education Model in Nursing Education. Dokuz Eylul University School of Nursing Electronic Journal, 6(4), 214-217.

Visoky, A. M., \& Poe, B. D. (2000). Can preschoolers be effective peer models? An action research project. Teaching Exceptional Children, 33(2), 68-73. https://doi.org/10.1177/004005990003300209

Warr-Leeper, G. (2001). A review of early intervention programs and effectiveness research for environmentally disadvantaged children. Journal of Speech-Language Pathology and Audiology, 24(2), 50-62.

Weaver, W., \& Cotrell, H. W. (1986). Peer Evaluation: A Case Study. Innovative Higher Education. 11, 25-39. https://doi.org/10.1007/BF01100106

Wolery, M., \& Wilbers, J. S. (1994). Including children with special needs in early childhood programs. Washington: National Association for the Education of Young Children.

Yildirim, A., \& Simsek, H. (2011). Qualitative research methods in the social sciences. Seckin Publishing: Ankara.

Yildirim, S. (2002). Akranlar tarafindan kullanilan sabit bekleme sureli ogretimin gelisimsel geriligi olan ogrencilere tanitici levhalarin ogretimi uzerindeki etkililigi. Unpublished master's thesis, Anadolu University, Eskisehir.

Yu T. C., Wilson, N. C., Singh, P. P., Lemanu, D. P., Hawken, S. J., \& Hill, A. G. (2011). Medical students-as-teachers: a systematic review of peer-assisted teaching during medical school. Advances in Medical Education and Practice, 2, 157-172.

\section{Appendix A}

Peer Student Evaluation Form

1. Were you satisfied with this practice conducted within the scope of the Community Service Practices course?

2. Which aspects of the practice were you satisfied with?

- In terms of peer teachers

- In terms of peer students

- In terms of the process

- Other

3. Which aspects of the practice were you dissatisfied with?

- In terms of peer teachers

- In terms of peer students

- In terms of the process

- Other

4. Do you think it would be beneficial if this practice conducted within the scope of the Community Service Practices course was maintained?

5. What are your recommendations for this practice conducted within the scope of the Community Service Practices course to be improved?

6. How did your peer teacher help you during the practice? Explain.

a) At knowledge level

b) At experiments level

c) At evaluation level

d) Other 


\section{Appendix B}

Peer Teacher Evaluation Form

1. Were you satisfied with this practice conducted within the scope of the Community Service Practices course?

2. Which aspects of the practice were you satisfied with?

- In terms of peer teachers

- In terms of peer students

- In terms of the process

- Other

3. Which aspects of the practice were you dissatisfied with?

- In terms of peer teachers

- In terms of peer students

- In terms of the process

- Other

4. Do you think it would be beneficial if this practice conducted within the scope of the Community Service Practices course was maintained?

5. What are your recommendations for this practice conducted within the scope of the Community Service Practices course to be improved?

6. How did you help your peer students during the practice? Explain.

a) At knowledge level

b) At experiments level

c) At evaluation level

d) Other

\section{Copyrights}

Copyright for this article is retained by the author(s), with first publication rights granted to the journal.

This is an open-access article distributed under the terms and conditions of the Creative Commons Attribution license which permits unrestricted use, distribution, and reproduction in any medium, provided the original work is properly cited. 